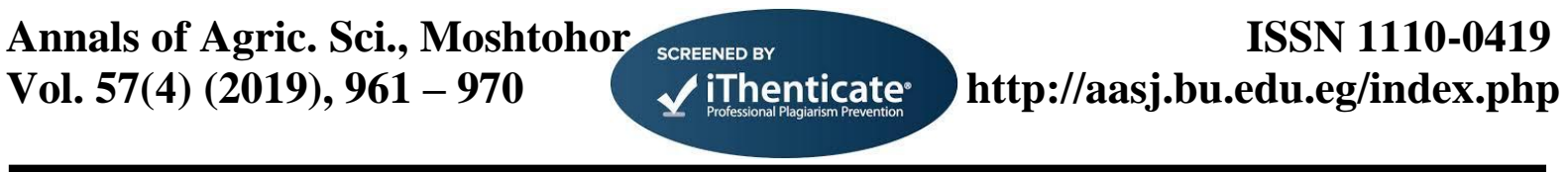

\title{
Evaluation of Selected Promising Bread Wheat lines in late Generations under Two Sowing Dates
}

Farhat, W. Z. E; Kh. I. Gad and M. A. A. Aglan

Wheat Research Department, Field Crops Research Institute, ARC, Egypt

Corresponding author: Momen.kfs@gmail.com

\begin{abstract}
Five parents and their derived $\mathrm{F}_{5}$ families (12 families) and new check variety Sakha 95 were evaluated under two sowing dates, optimum sowing (OS) and late sowing (LS) dates for earliness, yield and yield components. The study was laid out in RCBD experiment in four replications in the experimental farm at Sakha Research Station, KafrElsheikh Governorate. The analysis of variance showed the presence of highly significant differences between years, sowing dates and genotypes under study. Interactions between all studied characteristics were also significant except for No. of kernels spike ${ }^{-1}$ and No. of spikes $\mathrm{m}^{-2}$. Reductions in grain yield and its components were observed in the first season compared to the second season due to climatic conditions. Likewise, the values of the characteristics at the late planting date were less than the ones at the recommended date due to the effect of high temperatures at the end of the season. For the characteristics of the resistance to the rust, three families showed resistance to the three rusts in the two seasons, as well as on the two sowing dates. Therefore, these three families can be used in breeding for rust resistance.Family number 12 was the most tolerant to high temperatures at the end of the season after the comparative cultivar Sakha 95 and recorded the lowest percentage of decline in yield as a result of late planting, so it is recommended to plant them in the case of late planting.
\end{abstract}

Key words: Triticumaestivum, heading, maturity, yield components, late sowing.

\section{Introduction}

Wheat is one of the important staple cereal food of the world's population. About $20 \%$ of food calories for the world population are provided by wheat. It is considered an important cereal food crop due to its bread making quality. Great advantage of wheat cultivation results from the high level of yield, valuable chemical composition and wide possibilities of grain use for consumption purposes and for baking and feed purposes. An increase in grain yield (GY) is crucial for wheat crop competitiveness. Such increases may be accessible based upon the selection of adapted cultivars and adequate management practices. Wheat, GY is dependent on the environment, genetic factors and the interaction between them. In Egypt, many farmers prefer growing wheat after potato, sweet potato, peas and recently after early sugar beet. These crops harvested at late December or in January. Delayed sowing of wheat not only affects germination and growth but also affects grain developmentHayam and Amin, 2005). El-Kalla et al., 2010 reported that late sowing was unfavorable due to high temperature during anthesis. Also, a progressive decrease in yield components; i.e. number of grains per spike and kernel weight when sowing date was delayed from November to mid-January. So late planting is a major constraint facing increasing wheat production particularly in Middle Egypt. It has been reported that globally wheat production reduced with every $1^{\circ} \mathrm{C}$ rise of temperature by $6 \%$ during the growing season (Asseng et al. 2015). Variation in weather conditions among and within season is one of the most important constraints affecting yield potential (Murungu and Madanzi, 2010). Heat stress is one of the most important production challenges for wheat. The expected rising global temperature of 1$4^{\circ} \mathrm{C}$ over the next 50 years will have an effect on the production of wheat in the tropics through heat stress (Hansen, 2006). Heat stress affects more than 30 million hectares of wheat annually in the world leading to significant grain yield reduction Battisti and Naylor, 2009. To adapt new crop varieties to the future climate, we need to understand how crops respond to elevated temperatures and how tolerance to heat can be improved Halford, 2009. Success in crop improvement generally depends on the magnitude of genetic variability and the extent to which the desirable characters are important. Germplasm evaluation will be of great significance for selection of heat-tolerant genotypes and for improving grain yield under high temperature Tadesse et al. 201). Wheat breeders are seeking to incorporate late heat tolerance in the wheat germplasmto develop early maturing genotypes in order to escape the terminal heat stress Abd-Allah and Amin 2013.

The objectives of this study were to evaluate some bread wheat genotypes under two sowing dates (recommended and late), to determine the effect of sowing date on yield and yield components.

\section{Materials and Methods}

Five bread wheat genotypes (TriticumaestivumL.) were grown in season 2009/2010 to obtain three crosses (Yasin 2013). The chosen crosses were Misr 2 x Gemmeiza 9 (Late $\times$ Late), Line 14 x Line 15 (Early $\times$ Early) and Gemmeiza 9 x Line 13 (Late $\times$ Early) according to Wheat research department data. In all selection procedures pedigree method were used and 
the selection was performed only on the three rusts resistant plants. Then selection was done in $\mathrm{F}_{3}$ in season 2012/2013 and the 45 high yielding plants from 2700 plants (each cross consisted of 900 plants) were selected (Aglan and Farhat 2014a). The same work was performed in $\mathrm{F}_{4}$ (season 2013/2014) and the 30 high yielding plants were obtained from 2700 plants in 45 families (Aglan and Farhat 2014b). The thirty high yielding lines were evaluated in replicated trials (unpublished data) in $\mathrm{F}_{5}$ (season 2014/2015) and the 12 lines with highest grain yield were selected to the current study.

The twelve lines as well as the parentsMisr 2, Gemmeiza 9, Line 13, Line 14 and Sakha 95 as checks were used during 2015/16 and 2016/17 wheat growing seasons at the Experimental Farm Res. Sec. of Sakha Agricultural Research Station, Kafr El-Sheikh, Egypt ( $31^{\circ} 5^{\prime} 12^{\prime \prime}$ North, 30 56' 49" East). The pedigree and selection history of the used genotypes are listed in Table (1).

Table 1. Name, pedigree and selection history of the studied wheat genotypes.

\begin{tabular}{|c|c|c|c|}
\hline Name & Pedigree & Selection history & Earliness in maturity \\
\hline \multicolumn{4}{|c|}{ Used parents and checks } \\
\hline Misr 2 & SKAUZ / BAV92 & $\begin{array}{l}\text { CMSS96M03611S-1M- } \\
\text { 010SY-010M-010SY-8M- } \\
\text { 0Y-0S }\end{array}$ & Late \\
\hline Sakha 95 & $\begin{array}{l}\text { PASTOR // SITE / MO /3/ CHEN / AEGILOPS } \\
\text { SQUARROSA (TAUS) // BCN /4/ WBLL1. }\end{array}$ & $\begin{array}{l}\text { CMA01Y00158S- } \\
\text { 040POY-040M-030ZTM- } \\
\text { 040SY-26M-0Y-0SY-0S. }\end{array}$ & Late \\
\hline $\begin{array}{l}\text { Gemmeiz } \\
\text { a } 9\end{array}$ & Ald "S" / Huac // C74A. 630 / Sx & $\begin{array}{l}\text { CGM 4583-5GM-1GM- } \\
\text { 0GM }\end{array}$ & Late \\
\hline Line 13 & ATTILA*2/GIZA168 & S.15612-1S-1S-4S-0S & Early \\
\hline Line 14 & $\begin{array}{l}\text { GIZA168/5/MAI"S"/FJ//ENU"S"/3/KITO/POT } \\
\text { O19//MO/JUP/4/K134(60)VEE }\end{array}$ & $\begin{array}{l}\text { S.15410-19S-7S-2S- } \\
\text { 0SS.15410-19S-7S-2S-0S }\end{array}$ & Early \\
\hline Line 15 & $\begin{array}{l}\text { KAUZ/ATTILA/7/KVZ/4/CC/INIA/3/CNO//E } \\
\text { LGAU/SON64/5/SPARROW"S"/BROCHIS"S" } \\
\text { /6/BAYA"S"/IMU }\end{array}$ & S.15563-9S-3S-1S-0S & Early \\
\hline \multicolumn{4}{|c|}{ New lines } \\
\hline Line 1 & Misr2/Gemmeiza9 & $\begin{array}{l}\text { S. } 17135-24 S-1 S-1 S- \\
0 S\end{array}$ & \\
\hline Line 2 & Misr2/Gemmeiza9 & $\begin{array}{l}\text { S. } 17135-36 S-2 S-1 S- \\
0 S\end{array}$ & \\
\hline Line 3 & Misr2/Gemmeiza9 & $\begin{array}{l}\text { S. } 17135-37 S-1 S-1 S- \\
\text { OS }\end{array}$ & \\
\hline Line 4 & Misr2/Gemmeiza9 & $\begin{array}{l}\text { S. } 17135-42 S-1 S-1 S- \\
0 S\end{array}$ & \\
\hline Line 5 & Misr2/Gemmeiza9 & $\begin{array}{l}\text { S. } 17135-63 S-1 S-2 S- \\
\text { OS }\end{array}$ & \\
\hline Line 6 & Misr2/Gemmeiza9 & $\begin{array}{l}\text { S. } 17135-72 S-1 S-1 S- \\
0 S\end{array}$ & \\
\hline Line 7 & Misr2/Gemmeiza9 & $\begin{array}{l}\text { S. } 17135-82 S-1 S-1 S- \\
0 S\end{array}$ & \\
\hline Line 8 & $\begin{array}{l}\text { GIZA168/5/MAI"S"/FJ//ENU"S"/3/KITO/POTO19// } \\
\text { MO/JUP/4/K134(60)VEE/8/KAUZ/ATTILA/7/KVZ } \\
\text { /4/CC/INIA/3/CNO//ELGAU/SON64/5/SPARROW" } \\
\text { S"/BROCHIS"S"/6/BAYA"S"/IMU }\end{array}$ & $\begin{array}{l}\text { S. } 17136-6 S-1 S-1 S- \\
0 S\end{array}$ & \\
\hline Line 9 & $\begin{array}{l}\text { GIZA168/5/MAI"S"/FJ//ENU"S"/3/KITO/POTO19// } \\
\text { MO/JUP/4/K134(60)VEE/8/KAUZ/ATTILA/7/KVZ } \\
\text { /4/CC/INIA/3/CNO//ELGAU/SON64/5/SPARROW" } \\
\text { S"/BROCHIS"S"/6/BAYA"S"/IMU }\end{array}$ & $\begin{array}{l}\text { S. } 17136-51 S-1 S-1 S- \\
0 S\end{array}$ & \\
\hline Line 10 & $\begin{array}{l}\text { GIZA168/5/MAI"S"/FJ//ENU"S"/3/KITO/POTO19// } \\
\text { MO/JUP/4/K134(60)VEE/8/KAUZ/ATTILA/7/KVZ } \\
\text { /4/CC/INIA/3/CNO//ELGAU/SON64/5/SPARROW" } \\
\text { S"/BROCHIS"S"/6/BAYA"S"/IMU }\end{array}$ & $\begin{array}{l}\text { S. } 17136-71 S-1 S-2 S- \\
\text { OS }\end{array}$ & \\
\hline Line 11 & Gemmeiza9//ATTILA*2/GIZA168 & $\begin{array}{l}\text { S. } 17137-39 S-1 S-1 S- \\
0 S\end{array}$ & \\
\hline Line 12 & Gemmeiza9//ATTILA*2/GIZA168 & $\begin{array}{l}\text { S. } 17137-83 S-4 S-1 S- \\
0 S\end{array}$ & \\
\hline
\end{tabular}


These selected wheat genotypes were evaluated through two sowing dates experiments repeated in two seasons. The $1^{\text {stexperiment }}$ was panted at 28 November (as a recommended date), while the $2^{\text {nd }}$ one was planted at $28 \mathrm{Dec}$. (asa late planting date). All other culture practices were done asrecommended. The preceding crop was maize in the two seasons. The meteorological data for the two winter growing seasons from Sakha meteorological station are given in Table (2). A randomized complete block design (RCBD) in four replications was used for each sowing date. The plot area was $2.4 \mathrm{~m}^{2}$ and consisted of four rows, $3 \mathrm{~m}$ long and $20 \mathrm{~cm}$ apart $(3 \mathrm{~m} \times 0.8 \mathrm{~m})$. Grains were manually drilled in the rows at the rate of 300 seeds $\mathrm{m}^{-2}$.

The studied characters were: No. of days to heading and physiological maturity, calculated grain filling period, plant height $(\mathrm{cm})$, No. of spikes $\mathrm{m}^{-2}$, No. of kernels spike ${ }^{-1}, 1000$-kernel weight $(\mathrm{g})$, grain yield $\left(\mathrm{g} \mathrm{m}^{-2}\right)$, leaf rust (LR), yellow rust (YR) and stem rust (SR). For the three rusts, the visual types of the infection were considered resistant $(\mathrm{R})$, moderately resistant (MR), moderately susceptible (MS) and susceptible (S),in addition disease severity for leaf and stem rusts were recorded according to Stakman et al (1962). The rust score were used to select resistance lines.

The statistical analyses were performed using the statistical routines available in EXCEL (2016). However, the coefficients of variations in each sowing date in the two seasons was lower than $20 \%$, all sowing dates under the two seasons were included in the combined analysis (Gomez and Gomez 1984). Years were random, while the sowing dates and genotypes were fixed.

Table 2. Monthly mean of air temperature $\left(\mathrm{AT}^{\mathrm{O}} \mathrm{C}\right)$, relative humidity $(\mathrm{RH} \%)$ and rainfed (mm/month) in the winter seasons 2015/2016 and 2016/2017 at Sakha site.

\begin{tabular}{lcccccccc}
\hline \multirow{2}{*}{ Month } & \multicolumn{2}{c}{ AT $^{\mathrm{O}} \mathrm{C} 2015 / 2016$} & \multicolumn{2}{c}{ AT $^{\mathrm{O}} \mathrm{C} 2016 / 2017$} & \multicolumn{2}{c}{ RH\% } & \multicolumn{2}{c}{ Rainfed (mm) } \\
\cline { 2 - 9 } & Max.* & Min.** & Max. & Min. & $2015 / 16$ & $2016 / 17$ & $2015 / 16$ & $2016 / 17$ \\
\hline November & 26.8 & 10.9 & 23.6 & 10.1 & 67.6 & 65.8 & - & - \\
December & 22.6 & 8.5 & 20.4 & 6.4 & 72.5 & 60.0 & 90.0 & 14.6 \\
January & 21.0 & 5.7 & 10.1 & 8.6 & 71.3 & 63.1 & 18.3 & 32.5 \\
February & 21.6 & 7.0 & 11.3 & 9.5 & 65.7 & 70.7 & 22.9 & 32.7 \\
March & 22.5 & 6.7 & 14.1 & 12.1 & 70.1 & 91.5 & 13.6 & 42.8 \\
April & 26.4 & 9.9 & 19.0 & 17.0 & 66.1 & 89.7 & 11.1 & - \\
\hline May & 30.1 & 13.3 & 22.6 & 20.8 & 59.2 & 100.1 & - & - \\
\hline
\end{tabular}

$*$ Max $=$ maximum temperature, $* *$ Min $=$ minimum temperature.

\section{Results and Discussion}

\section{Analysis of variances}

Data in Table 3 showed the mean squares of the studied characters for genotypes across the two sowing dates and across the two seasons. The mean squares due to years, sowing dates and genotypes were highly significant for all studied characters except effect of years for No. of kernels spike ${ }^{-1}$ and grain yield plant $^{-1}$ which was insignificant. Interaction effect between years and sowing dates $(\mathrm{Y} \times \mathrm{SD})$ was insignificant for all studied characters except for days to maturity, grain filling period and plant height which were highly significant.Interactions between genotypes and years $(\mathrm{G} \times \mathrm{Y})$ and genotypes and sowing dates $(\mathrm{G} \times \mathrm{SD})$ were highly significant for all studied characters except for No. of kernels spike ${ }^{-1}$. Thetriple interaction between years, sowing and genotypes $(\mathrm{Y} \times \mathrm{G} \times \mathrm{SD})$ was highly significant for all studied characters except for no. of spikes $\mathrm{m}^{-2}$ and no. of kernels spike ${ }^{-1}$. These results indicated that both sowing date and genotypes in each assessment act independently on the above mentioned characters. These results were in line with those obtained by Kabir et al. (2017) and Yadav et al. (2018).

Mean performances
Data in Table 4 shows average values of all studied characters over the two sowing dates and seasons. The earliest genotype for days to heading and maturity was Line 8, while the latest ones were Line 4 and Line 2 for days to heading and maturity, respectively. Concerning grain filling period, the lowest value was 41.44 days for Line 7 , whereas the highest value 48.81 days was recoded for Line 9 . With regard to plant height the tallest genotype was line 5 $(124.69 \mathrm{~cm})$, while the shortest one was Line 10 $(106.25 \mathrm{~cm})$. With respect No. of spikes $\mathrm{m}^{-2}$ and No. of kernels spike $^{-1}$ the highest measurements (617.3\&66.88) were recorded for Line 12 and Line 7 respectively, whereas the lowest measurements were (449.98 \& 52.86) for Line 7 and Line 8, respectively. For 1000-kernel weight and grain yield plant ${ }^{-1}$, the highest recorded values were $(51.30 \& 861.93 \mathrm{~g})$ for Line 8 and Line 12, respectively, while the lowest ones were (43.47 \& 692.19) for Line 4 and Line 10 , respectively. For checks, the best check for days to heading and maturity was Line 13 . Sakha 95 was the best check for grain filling period, plant height, 1000kernel weight and grain yield plant ${ }^{-1}$, while for No. of spikes $\mathrm{m}^{-2}$ and No. of kernels spike ${ }^{-1}$ the best check was Misr 2 and Gemmeiza 9, respectively. 
Table 3. Mean squares of the studied wheat genotypes characters over the two seasons of 2015/2016 and $2016 / 2017$

\begin{tabular}{lccccccccc}
\hline \multicolumn{1}{c}{ SOV } & df & DH & DM & GP & PH & SM & KS & KW & GY \\
\hline Years (Y) & 1 & $3991.8^{* *}$ & $1740.2^{* *}$ & $460.7^{* *}$ & $5562.1^{* *}$ & $422466.2^{* *}$ & 44 & $5654.2^{* *}$ & 2377.5 \\
\hline Sowing dates & 1 & $7247.1^{* *}$ & $22941.2^{* *}$ & $4400.1^{* *}$ & $4209.2^{* *}$ & $335933.7^{* *}$ & $1704.6^{* *}$ & $5566.1^{* *}$ & $6391700.4^{* *}$ \\
(SD) & 1 & 3.3 & $460.7^{* *}$ & $385.9^{* *}$ & $229.8^{* *}$ & 76.9 & 3.9 & 1 & 3951 \\
Y x SD & 12 & 2.60 & 9.70 & 9.00 & 12.90 & 1542.10 & 17.30 & 4.70 & 3915.00 \\
Error a & 16 & $407.6^{* *}$ & $220.3^{* *}$ & $80.7^{* *}$ & $746.6^{* *}$ & $31700.3^{* *}$ & $315^{* *}$ & $95.8^{* *}$ & $52533.7^{* *}$ \\
Genotypes (G) & 16 & $8.3^{* *}$ & $7.8^{* *}$ & $10.2^{* *}$ & $26.8^{* *}$ & $6434.7^{* *}$ & 4 & $28.6^{* *}$ & $23367.6^{* *}$ \\
G x Y & 16 & $14.8^{* *}$ & $27.1^{* *}$ & $11.3^{* *}$ & $37.1^{* *}$ & $4270.4^{* *}$ & 18 & $34.8^{* *}$ & $22614.1^{* *}$ \\
G x SD & 16 & $9.3^{* *}$ & $12^{* *}$ & $20.9^{* *}$ & $21.8^{* *}$ & 2343.5 & 1.4 & $19.2^{* *}$ & $8962.9^{* *}$ \\
G x Y x SD & 192 & 1.10 & 1.50 & 1.80 & 10.10 & 2017.60 & 11.00 & 6.80 & 2417.10 \\
Pooled Error & 19 & & & & & & & \\
(Eb) & 271 & & & & & & & & \\
Total & & 1.12 & 0.88 & 3.01 & 2.82 & 8.54 & 5.88 & 5.55 & 6.30 \\
\hline CV
\end{tabular}

$\mathrm{DM}=$ Days to heading, $\mathrm{DM}=$ Days to maturity, $\mathrm{GP}=$ grain filling period, $\mathrm{PH}=$ Plant height, $\mathrm{SM}=$ no. of spikes $\mathrm{m}^{-2}, \mathrm{KS}=$ no. of kernels spike ${ }^{-1}, \mathrm{KW}=1000$ kernel weight, and GY = Grain yield

Table 4. Mean performance of all genotypes for all studied characters over the two sowing dates and the two seasons.

\begin{tabular}{|c|c|c|c|c|c|c|c|c|}
\hline Genotypes & $\mathrm{DH}$ & $\mathrm{DM}$ & GP & $\mathrm{PH}$ & SM & $\mathrm{KS}$ & KW & GY \\
\hline \multicolumn{9}{|l|}{ New lines } \\
\hline Line 1 & 98.00 & 143.38 & 45.38 & 107.50 & 491.47 & 64.67 & 44.77 & 796.51 \\
\hline Line 2 & 97.38 & 142.13 & 44.75 & 111.56 & 529.13 & 55.55 & 43.52 & 777.34 \\
\hline Line 3 & 95.81 & 140.50 & 44.69 & 119.06 & 502.23 & 57.27 & 47.02 & 811.35 \\
\hline Line 4 & 99.38 & 141.63 & 42.25 & 114.69 & 527.67 & 57.11 & 43.47 & 704.17 \\
\hline Line 5 & 96.38 & 139.69 & 43.31 & 124.69 & 553.58 & 57.97 & 46.31 & 791.41 \\
\hline Line 6 & 97.88 & 141.19 & 43.31 & 120.00 & 505.18 & 56.97 & 45.34 & 780.08 \\
\hline Line 7 & 98.19 & 139.63 & 41.44 & 120.94 & 449.98 & 66.88 & 46.27 & 811.20 \\
\hline Line 8 & 86.38 & 132.69 & 46.31 & 118.75 & 504.49 & 52.86 & 51.30 & 734.24 \\
\hline Line 9 & 89.44 & 138.25 & 48.81 & 108.13 & 510.21 & 56.09 & 47.20 & 769.87 \\
\hline Line 10 & 87.88 & 134.81 & 46.94 & 106.25 & 505.74 & 53.27 & 46.97 & 692.19 \\
\hline Line 11 & 91.94 & 136.00 & 44.06 & 108.44 & 495.95 & 57.60 & 49.86 & 801.56 \\
\hline Line 12 & 91.44 & 134.50 & 43.06 & 114.38 & 617.30 & 53.60 & 46.78 & 861.93 \\
\hline \multicolumn{9}{|l|}{ Checks } \\
\hline Misr 2 & 95.88 & 140.44 & 44.56 & 115.00 & 601.64 & 55.72 & 44.98 & 795.08 \\
\hline Gemmeiza9 & 98.06 & 141.88 & 43.81 & 113.44 & 477.76 & 58.91 & 47.06 & 741.30 \\
\hline Line 13 & 82.44 & 131.44 & 49.00 & 97.19 & 553.66 & 47.19 & 49.26 & 803.05 \\
\hline Line 14 & 88.25 & 135.31 & 47.06 & 106.56 & 533.26 & 53.54 & 49.00 & 691.15 \\
\hline Sakha 95 & 92.31 & 134.31 & 42.00 & 115.31 & 587.09 & 55.51 & 51.77 & 911.12 \\
\hline Minimum & 82.44 & 131.44 & 41.44 & 97.19 & 449.98 & 47.19 & 43.47 & 691.15 \\
\hline Maximum & 99.38 & 143.38 & 49.00 & 124.69 & 617.30 & 66.88 & 51.77 & 911.12 \\
\hline $\operatorname{LSD}_{(0.05)}$ & 0.73 & 0.85 & 0.94 & 2.22 & 31.32 & 2.32 & 1.82 & 34.28 \\
\hline
\end{tabular}

\section{Interaction effects}

\section{1- $\quad$ Effect over the two seasons}

Table (5) illustrates the average values of the agronomic characters across the two sowing dates in the two seasons. As in Table (2), there were manifested declines in the temperature throughout the second season compared to the first one. The means of all characters for all genotypes were significantly decreased in the first season except grain filling period (GP), representing seasonal differences. The earliest genotype for days to heading and maturity in the two seasons was Line8. For grain filling period and No. kernels spike ${ }^{-1}$ the best values were recorded for Line 7.With regard to plant height, the tallest genotype under the two seasons was Line 5. Concerning No. of spikes $\mathrm{m}^{-2}$ and grain yield plant $^{-1}$ the highest measurements were recorded for Line 12 in the two seasons. With regard to 1000-kernel weight the highest values were reported for Lines 8 and 11 in the $1^{\text {st }}$ and $2^{\text {nd }}$ seasons, respectively. Ali et al., 2010 and Gheith et al. (2013) reported that yield and yield components were reduced according to the climate changes from year to year. On the other hand, Bendidi et al. (2016) found that agronomic characters values were increased in the $2^{\text {nd }}$ season compared to the $1^{\text {st }}$ 
season due to climate changes.

\section{1- Effect over the two sowing dates}

The means of the all characters across the two seasons under the two sowing dates are presented in Table (6). The optimum sowing date showed the highest values for all characters, while, late sowing date produced the lowest values. These results may be due to the appropriate temperature at different developmental stages and consequently increased net assimilation rate. These results are in harmony with the findings of Riaz- Ud-Dinet al., 2010 and Talukderet al., 2014. Under the late sowing date, there was high temperature, especially during grain filling period, and resulted in reduction ingrain filling rate and grain yield, which could be due to the reduction in grain weight and shortened period to maturity RiazUd-Dinet al., 2010. Days to heading ranged from 83 days in Line 8 under the late sowing date to 105.5 days in Line 4 at the optimum sowing date. At the same time, days to maturing were within the range of 124.6 in Line 11 at the late sowing date to 153.8 in Line lunder the optimum sowing date. With respect to grain filling period the values ranged from 37.4 for Line 7 at late sowing date to 53.0 for Line 9 at optimum sowing date. For plant height the tallest genotype was Line $5(128.1 \mathrm{~cm})$ under optimum sowing date, whereas, the shortest genotype was Lines 10 and 11 at late sowing date. In addition, No. of spikes $\mathrm{m}^{-2}$ the measurement were between 398.9 for Line 7 under late sowing to 640.4 for Line 12 under optimum sowing date. No. of kernels spike ${ }^{-1}$ values between 49.3 in Line 8 and 68.6 in Line 7 in the late and optimum sowing date, respectively. The values of 1000 kernel weight ranged from $38.2 \mathrm{~g}$ in Line 2 to $56.2 \mathrm{~g}$ for Line 8 in the late and optimum sowing dates, respectively. Grain yield ranged from $487.9 \mathrm{~g}$ $\mathrm{m}^{-2}$ for Line 14 under the late sowing date to $984.4 \mathrm{~g}$ $\mathrm{m}^{-2}$ for Line 11 under the late and optimum sowing date, respectively. Concerning checks genotypes, Line 13 was the earliest check for days to heading and maturity and it was the heaviest genotype in 1000kernel weight in optimum sowing date. Sakha 95 was the best genotypes for grain filling period, plant height, No. of spikes $\mathrm{m}^{-2}$ and 1000-kernel weight in late sowing date and grain yield plant ${ }^{-1}$. Gemmeiza 9 was the best check for plant height in optimum sowing date and No. of kernels spike ${ }^{-1}$ at both sowing dates. Misr 2 was the best check for No. of spikes $\mathrm{m}^{-2}$ at optimum sowing date only.

The reduction $\%$ in grain yield due to late sowing reached the maximum value in Line $9(44.66 \%)$ followed by Line $10(43.46 \%)$, while the minimum value were detected by Line $12(18.44 \%)$. While for checks, reduction \% ranged from $16.86 \%$ in Sakha 95 to $46.99 \%$ in Line 14 . The variations in yield and yield contributing characters of wheat due to sowing dates were also observed byWyzińska and Grabiński 2018 and Yadav et al., 2018.

Table 5. Effect of the interactions between years and genotypes on all characters.

\begin{tabular}{|c|c|c|c|c|c|c|c|c|c|c|c|c|c|}
\hline \multirow[t]{3}{*}{ Genotypes } & \multicolumn{2}{|c|}{ DH } & DM & \multicolumn{2}{|c|}{ GP } & \multirow{2}{*}{\multicolumn{2}{|c|}{$\frac{\text { PH }}{2015 / 12016 / 1}$}} & SM & \multicolumn{2}{|c|}{$\mathrm{KS}$} & \multicolumn{2}{|c|}{$\mathrm{KW}$} & GY \\
\hline & $\overline{2015 / 1}$ & $2016 / 1$ & $2015 / 12016 / 1$ & $2015 / 1$ & $2016 / 1$ & & & $2015 / 12016 / 1$ & $2015 / 1$ & $2016 / 1$ & $2015 / 1$ & $2016 / 1$ & $2015 / 12016 / 1$ \\
\hline & 6 & 7 & $6 \quad 7$ & 6 & 7 & 6 & 7 & $6 \quad 7$ & 6 & 7 & 6 & 7 & $6 \quad 7$ \\
\hline \multicolumn{14}{|l|}{ Lines } \\
\hline Line 1 & 93.6 & IL. & 9.3147 .5 & 45.6 & 45.1 & 104 & 10 & 2.1520 .2 & 64.8 & 64.5 & 40.2 & 49.3 & 830.2762 .8 \\
\hline Line 2 & 93.0 & 01.8 & 139.0145 .3 & 46.0 & 43.5 & 108. & 114 & 91.8566 .5 & 54.9 & 56.2 & 40.2 & 46.9 & 797.1757 .6 \\
\hline Line 3 & 91.4 & 100.3 & 137.9143 .1 & 46.5 & 42.9 & 115.6 & 122.5 & 471.8532 .7 & 56.6 & 57.9 & 43.0 & 51.0 & 869.5753 .2 \\
\hline Line 4 & 95.1 & 103.6 & 39.5143 .8 & 44.4 & 40.1 & 1 & 118. & 86.0569 .3 & 56.8 & 57.4 & 37.4 & 49.6 & 738.3670 .1 \\
\hline Line 5 & 92.4 & 100.4 & 137.4142 .0 & 45.0 & 41.6 & 119.4 & 130.0 & 532.6574 .6 & 57.6 & 58.3 & 40.3 & 52.3 & 820.1762 .8 \\
\hline Line 6 & 93.8 & 102.0 & 138.9143 .5 & 45.1 & 41.5 & 116.3 & 123.8 & 481.8528 .6 & 55.7 & 58.3 & 41.9 & 48.8 & 784.9775 .3 \\
\hline Line 7 & 93.8 & 102.6 & 137.5141 .8 & 43.8 & 39.1 & 117.5 & 124.4 & 427.5472 .4 & 67.0 & 66.8 & 39.9 & 52.7 & 774.0848 .4 \\
\hline Line 8 & 83.0 & 89.8 & 130.0135 .4 & 47.0 & 45.6 & 112.5 & 125.0 & 454.5554 .4 & 52.5 & 53.3 & 49.9 & 52.7 & 734.4734 .1 \\
\hline Line 9 & 86.0 & 92.9 & 135.9140 .6 & 49.9 & 47.8 & 101. & 15. & 14.0576 .4 & 56.1 & 56.1 & 42.5 & 51.9 & 706.9832 .8 \\
\hline Line 10 & 85.1 & 90.6 & 132.3137 .4 & 47.1 & 46.8 & 100.6 & 111.9 & 446.0565 .4 & 53.4 & 53.2 & 41.9 & 52.1 & 636.7747 .7 \\
\hline Line 11 & 88.1 & 95.8 & 135.1136 .9 & 47.0 & 41.1 & 103.1 & 113.8 & 445.2546 .7 & 57.0 & 58.2 & 45.0 & 54.7 & 786.5816 .7 \\
\hline Line 12 & 86.8 & 96.1 & 131.5137 .5 & 44.8 & 41.4 & 110.0 & 118.8 & 574.8659 .7 & 53.2 & 54.0 & 41.2 & 52.4 & 922.4801 .5 \\
\hline \multicolumn{14}{|l|}{ Checks } \\
\hline Misr 2 & 93.3 & 98.5 & 8.5142 .4 & 45.3 & 43.9 & & & 3.0610 .3 & 56.2 & 55.2 & 41.3 & 48.7 & 764.3825 .8 \\
\hline $\begin{array}{l}\text { Gemmei } \\
\text { za } 9\end{array}$ & 93.5 & 102.6 & 138.4145 .4 & 44.9 & 42.8 & 108.8 & 118.1 & 403.9551 .6 & 57.8 & 60.0 & 42.2 & 51.9 & 691.4791 .3 \\
\hline Line 13 & 79.8 & 85.1 & 129.3133 .6 & 49.5 & 48.5 & 91.9 & 102.5 & 0.2557 .2 & 47.0 & 47.3 & 43.1 & 55.4 & 804.7801 .4 \\
\hline Line 14 & 85.4 & 91.1 & 132.8137 .9 & 47.4 & 46.8 & 100.6 & 112.5 & 472.6593 .9 & 53.0 & 54.1 & 44.5 & 53.5 & 675.0707 .3 \\
\hline Sakha 95 & 88.0 & 96.6 & 131.8136 .9 & 43.8 & 40.3 & 110.6 & 120.0 & 537.9636 .3 & 54.3 & 56.7 & 48.9 & 54.6 & 887.0935 .3 \\
\hline Minimum & 79.8 & 85.1 & 129.3133 .6 & 43.8 & 39.1 & 91.9 & 102.5 & 403.9472 .4 & 47.0 & 47.3 & 37.4 & 46.9 & 636.7670 .1 \\
\hline Maximum & 95.1 & 103.6 & 139.5147 .5 & 49.9 & 48.5 & 119.4 & 130.0 & 593.0659 .7 & 67.0 & 66.8 & 49.9 & 55.4 & 922.4935 .3 \\
\hline $\operatorname{LSD}_{(0.05)}$ & & 03 & 1.20 & & 33 & & 14 & 44.30 & & & & & 48.49 \\
\hline
\end{tabular}

$\mathrm{DH}=$ Days to heading, $\mathrm{DM}=$ Days to maturity, $\mathrm{GP}=$ grain filling period in days, $\mathrm{PH}=$ Plant height $(\mathrm{cm}), \mathrm{SM}=$ no. spikes $\mathrm{m}^{-2}, \mathrm{KS}=$ no. kernels spike ${ }^{-1}, \mathrm{KW}=1000$-kernel weight $(\mathrm{g})$ and $\mathrm{GY}=$ Grain yield $\left(\mathrm{g} \mathrm{m}^{-2}\right)$ 
Table 6. Effect of the interactions between sowing dates and genotypes for all agronomic characters over seasons

\begin{tabular}{|c|c|c|c|c|c|c|c|c|c|c|c|c|c|c|c|c|c|}
\hline \multirow{2}{*}{ Genotypes } & \multicolumn{2}{|c|}{$\mathrm{DH}$} & \multicolumn{2}{|c|}{ DM } & \multicolumn{2}{|c|}{ GFP } & \multicolumn{2}{|c|}{$\mathrm{PH}$} & \multicolumn{2}{|c|}{ SM } & \multicolumn{2}{|c|}{$\mathrm{KS}$} & \multicolumn{2}{|c|}{ KW } & \multicolumn{2}{|c|}{ GY } & \multirow{2}{*}{$\begin{array}{c}\text { G. Y } \\
\text { Reduction } \\
\%\end{array}$} \\
\hline & OS & $\mathrm{LS}$ & OS & $\mathrm{LS}$ & OS & LS & OS & $\mathrm{LS}$ & OS & $\mathrm{LS}$ & OS & LS & OS & LS & OS & $\mathrm{LS}$ & \\
\hline \multicolumn{18}{|l|}{ Lines } \\
\hline Line 1 & 103.9 & 92.1 & 153.8 & 133.0 & 49.9 & 40.9 & 113.1 & 101.9 & 510.2 & 472.8 & 67.5 & 61.8 & 46.8 & 42.8 & 951.3 & 641.7 & 32.54 \\
\hline Line 2 & 103.0 & 91.8 & 152.5 & 131.8 & 49. & 40.0 & 115.0 & 108.1 & 561.9 & 496.4 & 59.3 & 51.8 & 48.8 & 38.2 & 920.1 & 634.6 & 31.02 \\
\hline Line 3 & 101.6 & 90.0 & 149.6 & 131.4 & 48.0 & 41.4 & 121.3 & 116.9 & 552.8 & 451.6 & 62.0 & 52.6 & 50.2 & 43.8 & 977.6 & 645.1 & 34.01 \\
\hline Line 4 & 105.5 & 93.3 & 151.8 & 131.5 & 46.3 & 38.3 & 120.0 & 109.4 & 565.9 & 489.5 & 59.8 & 54.4 & 46.6 & 40.3 & 846.9 & 561.5 & 33.70 \\
\hline Line 5 & 101.8 & 91.0 & 148.3 & 131.1 & 46.5 & 40.1 & 128.1 & 121.3 & 579.8 & 527.4 & 60.1 & 55.8 & 51.0 & 41.6 & 936.7 & 646.1 & 31.03 \\
\hline Line 6 & 103.6 & 92.1 & 151.4 & 131.0 & 47.8 & 38.9 & 126.3 & 113.8 & 550.9 & 459.5 & 59.0 & 54.9 & 48.1 & 42.5 & 916.1 & 644.0 & 29.70 \\
\hline Line 7 & 103.6 & 92.8 & 149.1 & 130.1 & 45.5 & 37.4 & 124.4 & 117.5 & 501.1 & 398.9 & 68.6 & 65.1 & 53.2 & 39.4 & 965.4 & 657.0 & 31.94 \\
\hline Line 8 & 89.8 & 83.0 & 138.6 & 126.8 & 48.9 & 43.8 & 120.0 & 117.5 & 519.8 & 489.2 & 56.4 & 49.3 & 56.2 & 46.4 & 885.2 & 583.3 & 34.10 \\
\hline Line 9 & 94.4 & 84.5 & 147.4 & 129.1 & 53.0 & 44.6 & 111.3 & 105.0 & 548.9 & 471.5 & 59.7 & 52.4 & 51.7 & 42.7 & 975.5 & 564.2 & 44.46 \\
\hline Line 10 & 91.8 & 84.0 & 142.8 & 126.9 & 51.0 & 42.9 & 109.4 & 103.1 & 530.8 & 480.7 & 54.3 & 52.3 & 53.2 & 40.7 & 884.4 & 500.0 & 43.46 \\
\hline Line 11 & 97.0 & 86.9 & 147.4 & 124.6 & 50.4 & 37.8 & 113.8 & 103.1 & 530.7 & 461.2 & 60.6 & 54.6 & 55.4 & 44.3 & 984.4 & 618.8 & 36.74 \\
\hline Line 12 & 97.4 & 85.5 & 144.1 & 124.9 & 46.8 & 39.4 & 117.5 & 111.3 & 640.4 & 594.2 & 55.7 & 51.5 & 50.6 & 42.9 & 937.8 & 786.1 & 18.44 \\
\hline \multicolumn{18}{|l|}{ Checks } \\
\hline Misr 2 & 101. & 90.4 & 148.9 & 132.0 & 47.5 & 41.6 & 118.8 & 111.3 & 679.7 & 523.6 & 56.4 & 55.0 & 47.9 & 42.1 & 979.0 & 611.2 & 37.57 \\
\hline Gemmeiza 9 & 103.3 & 92.9 & 151.1 & 132.6 & 47.9 & 39.8 & 120.6 & 106.3 & 519.3 & 436.2 & 62.1 & 55.7 & 52.4 & 41.7 & 902.5 & 580.1 & 35.72 \\
\hline Line 13 & 85.9 & 79.0 & 139.0 & 123.9 & 53.1 & 44.9 & 100.6 & 93.8 & 562.2 & 545.1 & 49.0 & 45.4 & 56.1 & 42.4 & 918.4 & 687.7 & 25.13 \\
\hline Line 14 & 92.1 & 84.4 & 143.8 & 126.9 & 51.6 & 42.5 & 109.4 & 103.8 & 573.2 & 493.4 & 55.0 & 52.0 & 54.4 & 43.6 & 903.4 & 478.9 & 46.99 \\
\hline Sakha 95 & 98.9 & 85.8 & 144.5 & 124.1 & 45.6 & 38.4 & 119.4 & 111.3 & 616.3 & 557.9 & 57.5 & 53.5 & 55.2 & 48.4 & 995.0 & 827.2 & 16.86 \\
\hline Minimum & 85.9 & 79.0 & 138.6 & 123.9 & 45.5 & 37.4 & 100.6 & 93.8 & 501.1 & 398.9 & 49.0 & 45.4 & 46.6 & 38.2 & 846.9 & 478.9 & \\
\hline Maximum & 105.5 & 93.3 & 153.8 & 133.0 & 53.1 & 44.9 & 128.1 & 121.3 & 679.7 & 594.2 & 68.6 & 65.1 & 56.2 & 48.4 & 995.0 & 827.2 & \\
\hline & & & , & 20 & & & & & & 6 & & & & & & & \\
\hline
\end{tabular}

OS = Optimum sowing date, $\mathrm{LS}=$ Late sowing date,

$\mathrm{DH}=$ Days to heading, $\mathrm{DM}=$ Days to maturity, $\mathrm{GP}=$ grain filling period in days, $\mathrm{PH}=$ Plant height $(\mathrm{cm}), \mathrm{SM}=$ no. spikes $\mathrm{m}$

${ }^{2}, \mathrm{KS}=$ no. kernels spike ${ }^{-1}, \mathrm{KW}=1000-$ kernel weight $(\mathrm{g})$ and $\mathrm{GY}=$ Grain yield $\left(\mathrm{g} \mathrm{m}^{-2}\right)$

2- $\quad$ Effect of interactions among seasons, sowing dates and genotypes

The effect of interactions among seasons, sowing dates and genotypes on all characters are shown in Tables (7\&8). The late sowing date in the two growing seasons showed reduction in the means for days to heading, days to maturity, 1000-kernel weigh and grain yield. The maximum and minimum values of these characters tended to decrease under late sowing date in the two seasons. In this respect, Yunzea and Shuangsheng (2014) reported that the growth period of wheat was largely extended by shorter photoperiod before flowering, particularly the number of days from tillering to jointing and from jointing to heading. Also the period from flowering to maturity was extended by shorter photoperiod after flowering. For days to heading the values ranged from 78.8 days for Line 8 in $1^{\text {st }}$ season under late sowing to 109.5 days in the $2^{\text {nd }}$ season at optimum sowing date for Line 4 . With regard to days to maturity the lowest values was 121.3 days for Line 8 in the $1^{\text {st }}$ season under late sowing date and the highest one was recorded for Line $1 \quad 157.3$ days at $2^{\text {nd }}$ season under optimum sowing date. Grain filling period was ranged from 34.3 days for Line 11 in the $2^{\text {nd }}$ season under late sowing date to 54.5 days for Line 8 in the $1^{\text {st }}$ season under optimum sowing date. With respect to plant height, the tallest measure was $132.5 \mathrm{~cm}$ for Line 5 in the $2^{\text {nd }}$ seasons under optimum sowing date and the shortest measure was $95 \mathrm{~cm}$ for Line 10 in the $1^{\text {st }}$ season under late sowing date. For No. of spikes plant ${ }^{-1}$ the values were 683.4 for Line 12 and 380.3 for Line 7 in the $1^{\text {st }}$ season under optimum and late sowing dates, respectively. With regard to No. of kernels spike ${ }^{-1}$ the estimates ranged from 49.1 for Line 8 to 69.1 for Line 7 in the $1^{\text {st }}$ and $2^{\text {nd }}$ season under late and optimum sowing dates, respectively. With respect to 1000 kernel weight the values ranged from $33.2 \mathrm{gm}$ for Line 7 in the $1^{\text {st }}$ season under late sowing date to 59.9 for Line 7 in $2^{\text {nd }}$ season under optimum sowing date. Finally, for grain yield plant $^{-1}$ the estimates ranged from $466.7 \mathrm{gm}$ for Line 10 in the $1^{\text {st }}$ season under late sowing date to $1042.2 \mathrm{gm}$ for Line 9 in the $2^{\text {nd }}$ season under optimum sowing date. With respect to checks, Line 13 was the best check for days to heading and maturity and 1000 kernel weight. Sakha 95 was the best check for grain filling period, plant height and grain yield plant ${ }^{-1}$. Misr 2 and Gemmeiza 9 were the best checks for No. of spikes $\mathrm{m}^{-2}$ and No. of kernels spike ${ }^{-1}$, respectively.

Generally, all studied genotypes had short duration to heading and maturity under the late sowing date in the two seasons. Under the optimum sowing date, the studied genotypes were earlier in days to heading and maturity days in 2015/2016 season compared to the second one, while, late sowing date was vice versa. These results reflect the differences in climatic conditions during the two growing seasons Table 2. 
Table 7. Means of the days to heading, maturity, grain filling period and plant height of the 15 studied genotypes under optimum (OS) and late sowing dates (LS) during 2015/2016 and 2016/2017 seasons

\begin{tabular}{|c|c|c|c|c|c|c|c|c|c|c|c|c|c|c|c|c|}
\hline & \multicolumn{4}{|c|}{$\mathrm{DH}$} & \multicolumn{4}{|c|}{ DM } & \multicolumn{4}{|c|}{ GP } & \multicolumn{4}{|c|}{$\mathrm{PH}$} \\
\hline \multirow{2}{*}{$\begin{array}{c}\text { Years } \\
\text { Sowing } \\
\text { dates }\end{array}$} & \multicolumn{2}{|c|}{$2015 / 2016$} & \multicolumn{2}{|c|}{$2016 / 2017$} & \multicolumn{2}{|c|}{$2015 / 2016$} & \multicolumn{2}{|c|}{$2016 / 2017$} & \multicolumn{2}{|c|}{$2015 / 2016$} & \multicolumn{2}{|c|}{ 2016/2017 } & \multicolumn{2}{|c|}{$2015 / 2016$} & \multicolumn{2}{|c|}{$2016 / 2017$} \\
\hline & OS & $\mathrm{LS}$ & OS & LS & $\mathrm{OS}$ & $\mathrm{LS}$ & $\mathrm{OS}$ & $\mathrm{LS}$ & $\begin{array}{l}\mathrm{O} \\
\mathrm{S}\end{array}$ & $\mathrm{LS}$ & $\begin{array}{l}\mathrm{O} \\
\mathrm{S}\end{array}$ & LS & $\mathrm{OS}$ & $\mathrm{LS}$ & $\mathrm{OS}$ & LS \\
\hline \multicolumn{17}{|l|}{ Genotypes } \\
\hline \multicolumn{17}{|l|}{ Lines } \\
\hline Line 1 & $\begin{array}{c}99 . \\
3\end{array}$ & $\begin{array}{c}88 . \\
0\end{array}$ & $\begin{array}{c}108 . \\
5\end{array}$ & $\begin{array}{c}96 . \\
3\end{array}$ & $\begin{array}{c}150 . \\
3\end{array}$ & $\begin{array}{c}128 . \\
3\end{array}$ & $\begin{array}{c}157 . \\
3\end{array}$ & $\begin{array}{c}137 . \\
8\end{array}$ & $\begin{array}{c}51 . \\
0\end{array}$ & $\begin{array}{c}40 . \\
3\end{array}$ & $\begin{array}{c}48 . \\
8\end{array}$ & $\begin{array}{c}41 . \\
5\end{array}$ & $\begin{array}{c}110 . \\
0\end{array}$ & 98.8 & $\begin{array}{c}116 . \\
3\end{array}$ & $\begin{array}{c}105 . \\
0\end{array}$ \\
\hline Line 2 & $\begin{array}{c}98 . \\
0\end{array}$ & $\begin{array}{c}88 . \\
0\end{array}$ & $\begin{array}{c}108 . \\
0\end{array}$ & $\begin{array}{c}95 . \\
5\end{array}$ & $\begin{array}{c}151 . \\
0\end{array}$ & $\begin{array}{c}127 . \\
0\end{array}$ & $\begin{array}{c}154 . \\
0\end{array}$ & $\begin{array}{c}136 . \\
5\end{array}$ & $\begin{array}{c}53 . \\
0\end{array}$ & $\begin{array}{c}39 . \\
0\end{array}$ & $\begin{array}{c}46 . \\
0\end{array}$ & $\begin{array}{c}41 . \\
0\end{array}$ & $\begin{array}{c}113 . \\
8\end{array}$ & $\begin{array}{c}103 . \\
8\end{array}$ & $\begin{array}{c}116 . \\
3\end{array}$ & $\begin{array}{c}112 . \\
5\end{array}$ \\
\hline Line 3 & $\begin{array}{c}96 . \\
5\end{array}$ & $\begin{array}{c}86 . \\
3\end{array}$ & $\begin{array}{c}106 . \\
8\end{array}$ & $\begin{array}{c}93 . \\
8\end{array}$ & $\begin{array}{c}149 . \\
0\end{array}$ & $\begin{array}{c}126 . \\
8\end{array}$ & $\begin{array}{c}150 . \\
3\end{array}$ & $\begin{array}{c}136 . \\
0\end{array}$ & $\begin{array}{c}52 . \\
5\end{array}$ & $\begin{array}{c}40 . \\
5\end{array}$ & $\begin{array}{c}43 . \\
5\end{array}$ & $\begin{array}{c}42 . \\
3\end{array}$ & $\begin{array}{c}117 . \\
5\end{array}$ & $\begin{array}{c}113 . \\
8\end{array}$ & $\begin{array}{c}125 . \\
0\end{array}$ & $\begin{array}{c}120 . \\
0\end{array}$ \\
\hline Line 4 & $\begin{array}{c}101 . \\
5\end{array}$ & $\begin{array}{c}88 . \\
8\end{array}$ & $\begin{array}{c}109 . \\
5\end{array}$ & $\begin{array}{c}97 . \\
8\end{array}$ & $\begin{array}{c}151 . \\
3\end{array}$ & $\begin{array}{c}127 . \\
8\end{array}$ & $\begin{array}{c}152 . \\
3\end{array}$ & $\begin{array}{c}135 . \\
3\end{array}$ & $\begin{array}{c}49 . \\
8\end{array}$ & $\begin{array}{c}39 . \\
0\end{array}$ & $\begin{array}{c}42 . \\
8\end{array}$ & $\begin{array}{c}37 . \\
5\end{array}$ & $\begin{array}{c}117 . \\
5\end{array}$ & $\begin{array}{c}105 . \\
0\end{array}$ & $\begin{array}{c}122 . \\
5\end{array}$ & $\begin{array}{c}113 . \\
8\end{array}$ \\
\hline Line 5 & $\begin{array}{c}97 . \\
5\end{array}$ & $\begin{array}{c}87 . \\
3\end{array}$ & $\begin{array}{c}106 . \\
0\end{array}$ & $\begin{array}{c}94 . \\
8\end{array}$ & $\begin{array}{c}148 . \\
3\end{array}$ & $\begin{array}{c}126 . \\
5\end{array}$ & $\begin{array}{c}148 . \\
3\end{array}$ & $\begin{array}{c}135 . \\
8\end{array}$ & $\begin{array}{c}50 . \\
8\end{array}$ & $\begin{array}{c}39 . \\
3\end{array}$ & $\begin{array}{c}42 . \\
3\end{array}$ & $\begin{array}{c}41 . \\
0\end{array}$ & $\begin{array}{c}123 . \\
8\end{array}$ & $\begin{array}{c}115 . \\
0\end{array}$ & $\begin{array}{c}132 . \\
5\end{array}$ & $\begin{array}{c}127 \\
5\end{array}$ \\
\hline Line 6 & $\begin{array}{c}99 . \\
5\end{array}$ & $\begin{array}{c}88 . \\
0\end{array}$ & $\begin{array}{c}107 . \\
8\end{array}$ & $\begin{array}{c}96 . \\
3\end{array}$ & $\begin{array}{c}151 . \\
0\end{array}$ & $\begin{array}{c}126 . \\
8\end{array}$ & $\begin{array}{c}151 . \\
8\end{array}$ & $\begin{array}{c}135 . \\
3\end{array}$ & $\begin{array}{c}51 . \\
5\end{array}$ & $\begin{array}{c}38 . \\
8\end{array}$ & $\begin{array}{c}44 . \\
0\end{array}$ & $\begin{array}{c}39 . \\
0\end{array}$ & $\begin{array}{c}123 . \\
8\end{array}$ & $\begin{array}{c}108 . \\
8\end{array}$ & $\begin{array}{c}128 . \\
8\end{array}$ & $\begin{array}{c}118 . \\
8\end{array}$ \\
\hline Line 7 & $\begin{array}{c}98 . \\
5\end{array}$ & $\begin{array}{c}89 . \\
0\end{array}$ & $\begin{array}{c}108 . \\
8\end{array}$ & $\begin{array}{c}96 . \\
5\end{array}$ & $\begin{array}{c}148 . \\
5\end{array}$ & $\begin{array}{c}126 . \\
5\end{array}$ & $\begin{array}{c}149 . \\
8\end{array}$ & $\begin{array}{c}133 . \\
8\end{array}$ & $\begin{array}{c}50 . \\
0\end{array}$ & $\begin{array}{c}37 . \\
5\end{array}$ & $\begin{array}{c}41 . \\
0\end{array}$ & $\begin{array}{c}37 . \\
3\end{array}$ & $\begin{array}{c}122 . \\
5\end{array}$ & $\begin{array}{c}112 . \\
5\end{array}$ & $\begin{array}{c}126 . \\
3\end{array}$ & $\begin{array}{c}122 \\
5\end{array}$ \\
\hline Line 8 & $\begin{array}{c}87 . \\
3\end{array}$ & $\begin{array}{c}78 . \\
8\end{array}$ & 92.3 & $\begin{array}{c}87 . \\
3\end{array}$ & $\begin{array}{c}138 . \\
8\end{array}$ & $\begin{array}{c}121 . \\
3\end{array}$ & $\begin{array}{c}138 . \\
5\end{array}$ & $\begin{array}{c}132 . \\
3\end{array}$ & $\begin{array}{c}51 . \\
5\end{array}$ & $\begin{array}{c}42 . \\
5\end{array}$ & $\begin{array}{c}46 . \\
3\end{array}$ & $\begin{array}{c}45 . \\
0\end{array}$ & $\begin{array}{c}112 . \\
5\end{array}$ & $\begin{array}{c}112 . \\
5\end{array}$ & $\begin{array}{c}127 . \\
5\end{array}$ & $\begin{array}{c}122 . \\
5\end{array}$ \\
\hline Line 9 & $\begin{array}{c}91 . \\
8\end{array}$ & $\begin{array}{c}80 . \\
3\end{array}$ & 97.0 & $\begin{array}{c}88 . \\
8\end{array}$ & $\begin{array}{c}146 . \\
3\end{array}$ & $\begin{array}{c}125 \\
5\end{array}$ & $\begin{array}{c}148 . \\
5\end{array}$ & $\begin{array}{c}132 . \\
8\end{array}$ & $\begin{array}{c}54 . \\
5\end{array}$ & $\begin{array}{c}45 . \\
3\end{array}$ & $\begin{array}{c}51 . \\
5\end{array}$ & $\begin{array}{c}44 . \\
0\end{array}$ & $\begin{array}{c}105 . \\
0\end{array}$ & 97.5 & $\begin{array}{c}117 . \\
5\end{array}$ & $\begin{array}{c}112 . \\
5\end{array}$ \\
\hline Line 10 & $\begin{array}{c}90 . \\
3\end{array}$ & $\begin{array}{c}80 . \\
0\end{array}$ & 93.3 & $\begin{array}{c}88 . \\
0\end{array}$ & $\begin{array}{c}141 . \\
0\end{array}$ & $\begin{array}{c}123 . \\
5\end{array}$ & $\begin{array}{c}144 . \\
5\end{array}$ & $\begin{array}{c}130 . \\
3\end{array}$ & $\begin{array}{c}50 . \\
8\end{array}$ & $\begin{array}{c}43 . \\
5\end{array}$ & $\begin{array}{c}51 . \\
3\end{array}$ & $\begin{array}{c}42 . \\
3\end{array}$ & $\begin{array}{c}106 . \\
3\end{array}$ & 95.0 & $\begin{array}{c}112 . \\
5\end{array}$ & $\begin{array}{c}111 . \\
3\end{array}$ \\
\hline Line 11 & $\begin{array}{c}93 . \\
0\end{array}$ & $\begin{array}{c}83 . \\
3\end{array}$ & $\begin{array}{c}101 . \\
0\end{array}$ & $\begin{array}{c}90 . \\
5\end{array}$ & $\begin{array}{c}145 . \\
8\end{array}$ & $\begin{array}{c}124 . \\
5\end{array}$ & $\begin{array}{c}149 . \\
0\end{array}$ & $\begin{array}{c}124 . \\
8\end{array}$ & $\begin{array}{c}52 . \\
8\end{array}$ & $\begin{array}{c}41 . \\
3\end{array}$ & $\begin{array}{c}48 . \\
0\end{array}$ & $\begin{array}{c}34 . \\
3\end{array}$ & $\begin{array}{c}108 . \\
8\end{array}$ & 97.5 & $\begin{array}{c}118 . \\
8\end{array}$ & $\begin{array}{c}108 . \\
8\end{array}$ \\
\hline Line 12 & $\begin{array}{c}92 . \\
8\end{array}$ & $\begin{array}{c}80 . \\
8\end{array}$ & $\begin{array}{c}102 . \\
0\end{array}$ & $\begin{array}{c}90 . \\
3\end{array}$ & $\begin{array}{c}141 . \\
3\end{array}$ & $\begin{array}{c}121 . \\
8\end{array}$ & $\begin{array}{c}147 . \\
0\end{array}$ & $\begin{array}{c}128 . \\
0\end{array}$ & $\begin{array}{c}48 . \\
5\end{array}$ & $\begin{array}{c}41 . \\
0\end{array}$ & $\begin{array}{c}45 . \\
0\end{array}$ & $\begin{array}{c}37 . \\
8\end{array}$ & $\begin{array}{c}113 . \\
8\end{array}$ & $\begin{array}{c}106 . \\
3\end{array}$ & $\begin{array}{c}121 . \\
3\end{array}$ & $\begin{array}{c}116 . \\
3\end{array}$ \\
\hline Checks & & & & & & & & & & & & & & & & \\
\hline Misr 2 & $\begin{array}{c}97 . \\
5\end{array}$ & $\begin{array}{c}89 . \\
0\end{array}$ & $\begin{array}{c}105 . \\
3\end{array}$ & $\begin{array}{c}91 . \\
8\end{array}$ & $\begin{array}{c}148 . \\
3\end{array}$ & $\begin{array}{c}128 . \\
8\end{array}$ & $\begin{array}{c}149 . \\
5\end{array}$ & $\begin{array}{c}135 . \\
3\end{array}$ & $\begin{array}{c}50 . \\
8\end{array}$ & $\begin{array}{c}39 . \\
8\end{array}$ & $\begin{array}{c}44 . \\
3\end{array}$ & $\begin{array}{c}43 . \\
5\end{array}$ & $\begin{array}{c}120 . \\
0\end{array}$ & $\begin{array}{c}105 . \\
0\end{array}$ & $\begin{array}{c}117 . \\
5\end{array}$ & $\begin{array}{c}117 . \\
5\end{array}$ \\
\hline $\begin{array}{c}\text { Gemmeiza } \\
9\end{array}$ & $\begin{array}{c}98 . \\
3\end{array}$ & $\begin{array}{c}88 . \\
8\end{array}$ & $\begin{array}{c}108 . \\
3\end{array}$ & $\begin{array}{c}97 . \\
0\end{array}$ & $\begin{array}{c}148 . \\
8\end{array}$ & $\begin{array}{c}128 . \\
0\end{array}$ & $\begin{array}{c}153 . \\
5\end{array}$ & $\begin{array}{c}137 . \\
3\end{array}$ & $\begin{array}{c}50 . \\
5\end{array}$ & $\begin{array}{c}39 . \\
3\end{array}$ & $\begin{array}{c}45 . \\
3\end{array}$ & $\begin{array}{c}40 . \\
3\end{array}$ & $\begin{array}{c}117 . \\
5\end{array}$ & $\begin{array}{c}100 . \\
0\end{array}$ & $\begin{array}{c}123 . \\
8\end{array}$ & $\begin{array}{c}112 . \\
5\end{array}$ \\
\hline Line 13 & $\begin{array}{c}84 . \\
3\end{array}$ & $\begin{array}{c}75 . \\
3\end{array}$ & 87.5 & $\begin{array}{c}82 . \\
8\end{array}$ & $\begin{array}{c}139 . \\
0\end{array}$ & $\begin{array}{c}119 . \\
5\end{array}$ & $\begin{array}{c}139 . \\
0\end{array}$ & $\begin{array}{c}128 . \\
3\end{array}$ & $\begin{array}{c}54 . \\
8\end{array}$ & $\begin{array}{c}44 . \\
3\end{array}$ & $\begin{array}{c}51 . \\
5\end{array}$ & $\begin{array}{c}45 . \\
5\end{array}$ & 95.0 & 88.8 & $\begin{array}{c}106 . \\
3\end{array}$ & 98.8 \\
\hline Line 14 & $\begin{array}{c}90 . \\
5\end{array}$ & $\begin{array}{c}80 . \\
3\end{array}$ & 93.8 & $\begin{array}{c}88 . \\
5\end{array}$ & $\begin{array}{c}142 . \\
0\end{array}$ & $\begin{array}{c}123 . \\
5\end{array}$ & $\begin{array}{c}145 . \\
5\end{array}$ & $\begin{array}{c}130 . \\
3\end{array}$ & $\begin{array}{c}51 . \\
5\end{array}$ & $\begin{array}{c}43 . \\
3\end{array}$ & $\begin{array}{c}51 . \\
8\end{array}$ & $\begin{array}{c}41 . \\
8\end{array}$ & $\begin{array}{c}103 . \\
8\end{array}$ & 97.5 & $\begin{array}{c}115 . \\
0\end{array}$ & $\begin{array}{c}110 . \\
0\end{array}$ \\
\hline Sakha 95 & $\begin{array}{c}95 . \\
3\end{array}$ & $\begin{array}{c}80 . \\
8\end{array}$ & $\begin{array}{c}102 . \\
5\end{array}$ & $\begin{array}{c}90 . \\
8\end{array}$ & $\begin{array}{c}142 . \\
8\end{array}$ & $\begin{array}{c}120 . \\
8\end{array}$ & $\begin{array}{c}146 . \\
3\end{array}$ & $\begin{array}{c}127 . \\
5\end{array}$ & $\begin{array}{c}47 . \\
5\end{array}$ & $\begin{array}{c}40 . \\
0\end{array}$ & $\begin{array}{c}43 . \\
8\end{array}$ & $\begin{array}{c}36 . \\
8\end{array}$ & $\begin{array}{c}116 . \\
3\end{array}$ & $\begin{array}{c}105 . \\
0\end{array}$ & $\begin{array}{c}122 . \\
5\end{array}$ & $\begin{array}{c}117 . \\
5\end{array}$ \\
\hline Minmum & $\begin{array}{c}84 . \\
3\end{array}$ & $\begin{array}{c}75 . \\
3\end{array}$ & 87.5 & $\begin{array}{c}82 . \\
8\end{array}$ & $\begin{array}{c}138 . \\
8\end{array}$ & $\begin{array}{c}119 . \\
5\end{array}$ & $\begin{array}{c}138 . \\
5\end{array}$ & $\begin{array}{c}124 . \\
8\end{array}$ & $\begin{array}{c}47 . \\
5\end{array}$ & $\begin{array}{c}37 . \\
5\end{array}$ & $\begin{array}{c}41 . \\
0\end{array}$ & $\begin{array}{c}34 . \\
3\end{array}$ & 95.0 & 88.8 & $\begin{array}{c}106 . \\
3\end{array}$ & 98.8 \\
\hline Maximum & $\begin{array}{c}101 . \\
5\end{array}$ & $\begin{array}{c}89 . \\
0 \\
\end{array}$ & $\begin{array}{c}109 . \\
5 \\
\end{array}$ & $\begin{array}{c}97 . \\
8 \\
\end{array}$ & $\begin{array}{c}151 . \\
3 \\
\end{array}$ & $\begin{array}{c}128 . \\
8 \\
\end{array}$ & $\begin{array}{c}157 . \\
3 \\
\end{array}$ & $\begin{array}{c}137 . \\
8 \\
\end{array}$ & $\begin{array}{c}54 . \\
8 \\
\end{array}$ & $\begin{array}{c}45 . \\
3 \\
\end{array}$ & $\begin{array}{c}51 . \\
8 \\
\end{array}$ & $\begin{array}{c}45 . \\
5 \\
\end{array}$ & $\begin{array}{c}123 . \\
8 \\
\end{array}$ & $\begin{array}{c}115 . \\
0 \\
\end{array}$ & $\begin{array}{c}132 . \\
5 \\
\end{array}$ & $\begin{array}{c}127 . \\
5 \\
\end{array}$ \\
\hline LSD0.05 & & & & & & & & & & & & & & & & \\
\hline
\end{tabular}

$\mathrm{DH}=$ Days to heading, DM = Days to maturity, GP = grain filling period in days, $\mathrm{PH}=\mathrm{Plant}$ height $(\mathrm{cm})$

The means and ranges of reduction percentage for the agronomic characters of the tested new early lines are listed in Table 9. The average reduction due to late sowing date ranged from $8.08 \%$ and $5 \%$ for No. of kernels spike $^{-1}$ and plant height under $1^{\text {st }}$ and $2^{\text {nd }}$ seasons, respectively, to $33.81 \%$ and $31.82 \%$ for grain yield in the $1^{\text {st }}$ and $2^{\text {nd }}$ seasons, respectively. Grain yield in the two seasons was the most affected character by late sowing date. Similar findings were obtained by Ali et al., 2010 and Acharya et al., 2017.

Data in table 10 showed the reaction of the new evaluated lines to the three rusts, leaf rust (LR), yellow rust (YR) and stem rust (SR). Rusts estimated were used as criteria todifferentiate between lines. Lines
$1 \& 6$ had resistance reactions to the three rusts under optimum and late sowing dates. Line 3 also was resistance to leaf and yellow rusts. Therefore, those lines could be used as a source for resistance for these rusts.

\section{Conclusion}

It could be suggested according to this study that Line 12 could be reevaluated on the national level to confirm these results. Lines 1 and 3 could be used in breeding program to improve leaf and yellow rust resistance; in addition line 6 could be used as a source of resistance to the three rusts. Also, Line 12 was appropriate genotypes to be cultivated under late sowing dates. 


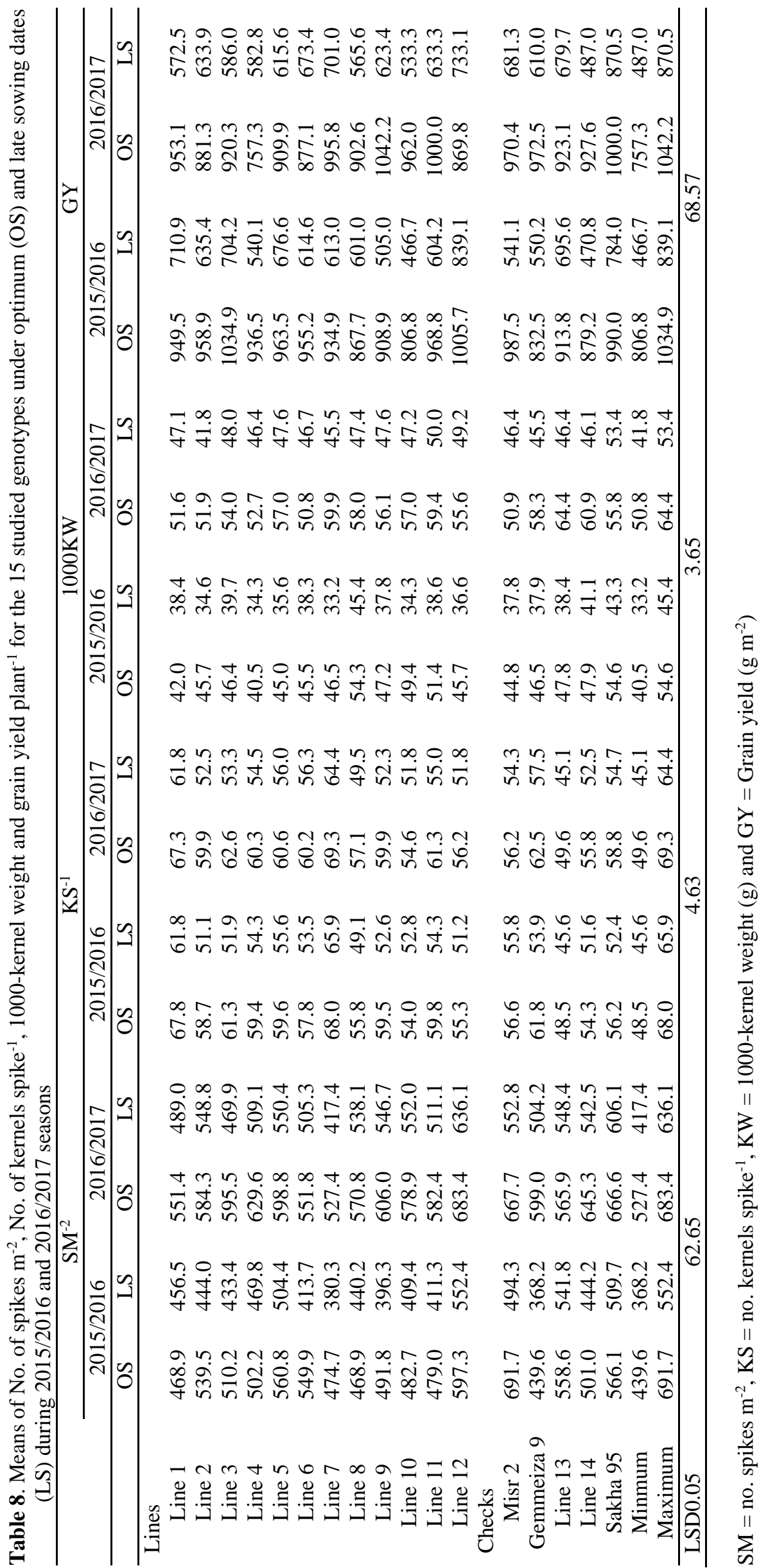


Table 9. Means and ranges of reduction in due to late sowing date for the all studied characters during 2015/16 and 2016/2017 seasons.

\begin{tabular}{lcccc}
\hline \multirow{2}{*}{\multicolumn{1}{c}{ Characters }} & \multicolumn{3}{c}{ Reduction \% } \\
\cline { 2 - 5 } & $2015 / 2016$ & $2016 / 2017$ & $2015 / 2016$ & $2016 / 2017$ \\
\cline { 2 - 5 } & 11.12 & 9.74 & $8.72-15.22$ & $5.42-12.83$ \\
\hline Days to heading & 14.34 & 10.57 & $12.41-16.06$ & $4.51-16.28$ \\
Days to maturity & 20.31 & 11.98 & $14.29-26.42$ & $1.69-28.65$ \\
Grain filling rate & 8.50 & 5.00 & $0-14.89$ & $0-9.68$ \\
Plant height & 13.41 & 11.50 & $2.65-28.53$ & $3.1-21.1$ \\
No. of spikes m ${ }^{-2}$ & 8.08 & 8.78 & $1.4-15.42$ & $3.51-14.95$ \\
No. kernels spike & 19.31 & 15.57 & $8.42-30.71$ & $4.16-27.89$ \\
1000-kernel weight & 33.81 & 31.82 & $16.57-46.45$ & $12.95-47.5$ \\
Grain yield & & & & \\
\hline
\end{tabular}

Table 10. The three rusts reaction mean in the two seasons under the two sowing dates for the new selected lines.

\begin{tabular}{|c|c|c|c|c|c|c|}
\hline Rust & \multicolumn{2}{|c|}{ LR } & \multicolumn{2}{|c|}{ YR } & \multicolumn{2}{|c|}{ SR } \\
\hline Genotypes & $\mathrm{OS}$ & $\mathrm{LS}$ & $\mathrm{OS}$ & $\mathrm{LS}$ & $\mathrm{OS}$ & $\mathrm{LS}$ \\
\hline Line 1 & 0 & 0 & 0 & Tr MS & $\operatorname{Tr} \mathrm{R}$ & $\operatorname{Tr} \mathrm{R}$ \\
\hline Line 2 & $\operatorname{Tr} \mathrm{S}$ & $\operatorname{Tr} \mathrm{S}$ & 0 & $\operatorname{Tr} M S$ & $\operatorname{Tr} \mathrm{S}$ & $10 \mathrm{~S}$ \\
\hline Line 3 & 0 & 0 & 0 & Tr MR & $10 \mathrm{~S}$ & $50 \mathrm{~S}$ \\
\hline Line 4 & $5 \mathrm{~S}$ & $20 \mathrm{~S}$ & 0 & Tr MR & $\operatorname{Tr} \mathrm{R}$ & $5 \mathrm{MR}$ \\
\hline Line 5 & $\operatorname{Tr} \mathrm{S}$ & $10 \mathrm{~S}$ & 0 & 0 & $10 \mathrm{~S}$ & $50 \mathrm{~S}$ \\
\hline Line 6 & 0 & 0 & 0 & 0 & $\operatorname{Tr} \mathrm{R}$ & Tr MR \\
\hline Line 7 & $5 \mathrm{~S}$ & $10 \mathrm{~S}$ & 0 & Tr MR & $\operatorname{Tr} \mathrm{R}$ & $5 \mathrm{MR}$ \\
\hline Line 8 & $5 \mathrm{MS}$ & $\operatorname{Tr} \mathrm{S}$ & 0 & 0 & Tr MS & $10 \mathrm{~S}$ \\
\hline Line 9 & $\operatorname{Tr} S$ & $\operatorname{Tr} \mathrm{S}$ & 0 & Tr MR & $10 \mathrm{~S}$ & $10 \mathrm{~S}$ \\
\hline Line 10 & $5 \mathrm{~S}$ & $5 \mathrm{~S}$ & 0 & 0 & Tr MS & $10 \mathrm{~S}$ \\
\hline Line 11 & $\operatorname{Tr} \mathrm{S}$ & $10 \mathrm{~S}$ & 0 & $\operatorname{Tr} M R$ & $\operatorname{Tr} \mathrm{R}$ & $\operatorname{Tr} \mathrm{R}$ \\
\hline Line 12 & $50 \mathrm{~S}$ & $50 \mathrm{~S}$ & 0 & 0 & Tr MR & $10 \mathrm{~S}$ \\
\hline
\end{tabular}

OS = Optimum sowing date, $\mathrm{LS}=$ Late sowing date,

\section{References}

Abd-Allah Soheir and MH, Amin, I.A. (2013). Genotypic differences for heat tolerance traits in bread wheat using five parameters genetic model. Alex. J. Agric. Res. Vol. 58, No.2:83-96.

Acharya, R. ; Marahatta, S. and Amgain, L. (2017). Response of Wheat Cultivars in Different Agricultural Practices Differed by Sowing Date. Int. J. Appl. Sci. Biotechnol. Vol 5(2): 250-255

Aglan M. A. and W. Z. E. Farhat (2014a). Genetic studies on some earliness and agronomic characters in advanced generations in bread wheat TriticumaestivumL. International J. of Plant \& Soil Sci., 36: 790-798, 2014.

Aglan M. A, and W. Z. E Farhat (2014b). Genetic studies on some F4 families of three bread wheat Triticumaestivumcrosses under optimum and late sowing dates. J. Agric. Res. KafrEl-Sheikh Univ. 40 (4): $.884-903$.

Asseng S., F. Ewert, P. Martre, R. P. Rtter, D. B. Lobell and D. Cammarano (2015). Rising temperature reduce global wheat production. Nature Climate change 5: 143- 147.

Ali M. A., M. Ali, S. Sattar and L. Ali.(2010). Sowing date effect on yield of different wheat varieties. J. Agric. Res., 48(2): 157-162
Battisti D.S. and R. L. Naylor. (2009), "Historical warning of future food insecurity with seasonal heat", Science, Vol. 9 No. 323 (5911): 240-4.

Bendidi A., K. Daoui, A. Kajji, L. Bouichou, M. Ben Bella, M. Ibriz and R. Dahan.(2016). Response of Bread Wheat to Sowing Dates and the Genotypes in Morocco. J. Experimental Agri. Int., 14(6): 1-8,

El-Kalla S. E.; A. A. Leillah; M. I. El-Emery and A. M.S. Kishk (2010). Performance of some wheat (Triticumaestivum L.) cultivars under late sowing date in newly reclaimed soils. J. Plant Prod., Mansoura Univ.,Vol. 1 (5): 689 - 697.

EXCEL.Microsoft EXCEL Computer user's guide; 2016.

Gheith E.M.S., Ola Z. El-Badry and S.A. Wahid.(2013). Sowing dates and nitrogen fertilizer levels effect on grain yield and its components of different wheat genotypes. Res. J. Agri. and Biological Sci. 9(5): 176-181

Gomez K. M. and A. A. Gomez (1984).Statistical procedures for agricultural research. John Wily and Sons, New York, $2^{\text {nd }}$ ed., 68P.

Halford N.G. (2009). New insights on the effects of heat stress on crops.J. of Experimental Botany, Vol. 60 No. 15, pp. 4215-4216.

Hansen J. (2006), "Global temperature change", Proceedings of the National Academy of Sciences of the United States of America, Vol. 103 No. 39, pp. 14288-14293. 
Hayam S. Mahgoub and I. Amin (2005). Effect of late sowing on two new released bread wheat cultivars. First Field Crops Proceeding., 22-24Aug 2006. 415-422.

Kabir R., I. Ahmed, A. Ur Rehman, M.Qamar, AnisaIntikhab, A. Rasheed, M. Zakriya, M. A.Muneer, and Z. Un-Nisa. (2017). Evaluation of bread wheat genotypes for variability and association among yield and yield related traits. Int. J. of Biosciences. Vol. 11, No. 1, p. 7-14

Murungu F.S. and T. Madanzi, 2010.Seed priming, genotype and sowing date effects on emergence, growth and yield in a tropical low altitude area of Zimbabwe. Afr. J. Agric. Res., 5(17): 2341-2349.

Riaz- Ud-Din R., G. M. Subhani, N. Ahmad, M. Hussain, A. Ur- Rehman (2010).Effect of temperature on development and grain formation in spring wheat. Pak. J.Bot., 42 (2): 899-906.

Stakman E.C.:D. M. Stewart and W. Q. Loegering (1962). Identification of physiologic races of Pucciniagraminis var. Tritici.ARsS, USDA.,Agr. Res. Serv. Bull. E6/7.53PP.

Tadesse W., E. M. Elbashier, E. M. E. Elbashier, S. E. Idris,I. S. A. Tahir, A. S.Ibrahim, A. M. A. Elhashimi, S. I. Saad, Amani, A. idris andHala, M.
Mustfa (2019). Genetic variations, heritability, heat tolerance indices and correlations studies for traits of bread wheat genotypes under high temperature. Int. J. Climate Change Strategies and Management. 11, (5):672-686.

Talukder A.S.M.H.M., G. K. McDonald and G. S. Gill (2014). Effect of short-term heat stress prior to flowering and at early grain set on the utilization of water-soluble carbohydrate by wheat genotypes. Field Crops Research 147:1-11.

Wyzińska M.and Grabiński, J. (2018).The influence of autumn sowing date on the productivity of spring wheat (Triticumaestivum L.).Res.For Rural Development. V. 2: 35-41.

Yadav M., Devokta, M. W., Sah, S. K. and Bhatt, R. (2018).Effect of sowing date on yield and yield components of different wheat varieties. Nepales J. Agri. Sci. 16:96-102.

Yasin M. (2013). Breeding for drought Tolerance in Bread Wheat.Ph. D. Thesis, Mansoura Univ., Egypt.

Yunzea S. and G. Shuangsheng (2014).Effects of photoperiod on wheat growth, development and yield in CELSS.ActaAstronautica, 105 (1): 24-29.

$$
\begin{aligned}
& \text { تقييم بعض السلالات المبشرة المنتخبة في الأجيال المتأخرة تحت ميعادي زراعة } \\
& \text { وليد ذكي اليماني فرحات * خالد إبراهيم جاد*"، مؤمن عبد الوهاب عجلان }
\end{aligned}
$$

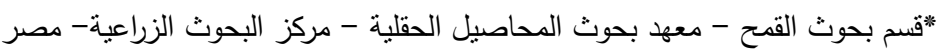

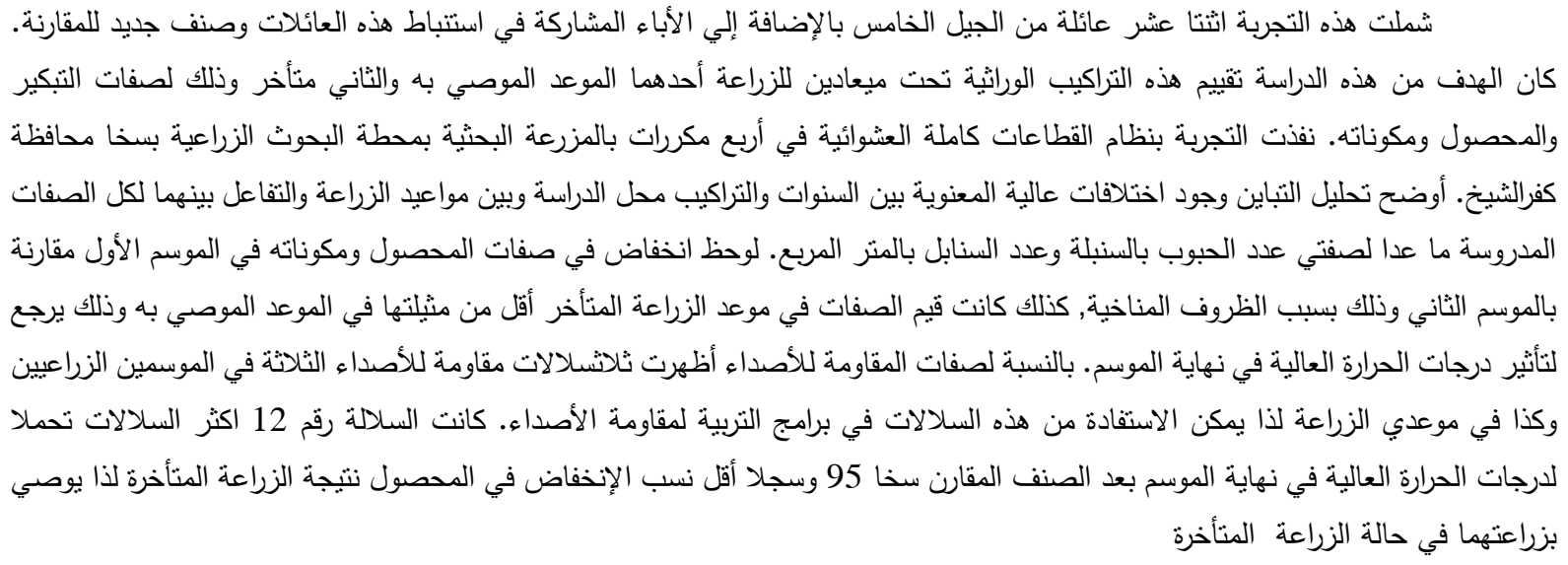

